\title{
ACELLULAR AND “LOW” PERTUSSIS VACCINES: ADVERSE EVENTS AND THE ROLE OF MUTATIONS
}

\author{
Hisako G. HIGASHI(1), Expedito LUNA(2), Alexander R. PRECIOSO(3), Marluce VILELA(4), Flávia S. KUBRUSLY(5), Waldely O. DIAS(5) \& Isaias RAW(5)
}

\begin{abstract}
SUMMARY
Objective: to discuss the current PAHO recommendation that does not support the substitution of traditional cellular DTP vaccine by acellular DTP, and the role of mutations, in humans, as the main cause of rare adverse events, such as epileptic-like convulsions, triggered by pertussis vaccine.

Data review: the main components related to toxic effects of cellular pertussis vaccines are the lipopolysaccharide of bacterial cell wall and pertussis toxin. The removal of part of lipopolysaccharide layer has allowed the creation of a safer cellular pertussis vaccine, with costs comparable to the traditional cellular vaccine, and which may be a substitute for the acellular vaccine.

Conclusion: The new methodology introduced by Instituto Butantan allows for the development of a new safer pertussis vaccine with low LPS content (Plow), and the use of the lipopolysaccharide obtained in the process in the production of monophosphoryl lipid A. This component has shown potent adjuvant effect when administered together with influenza inactivated vaccine, making possible to reduce the antigen dose, enhancing the production capacity and lowering costs.
\end{abstract}

KEYWORDS: Pertussis vaccine; Vaccine adverse events; Acellular pertussis vaccine; Low pertussis vaccine.

\section{DTP TOXINS ACTION MECHANISMS}

Clostridium tetani is a rod-shaped, anaerobic bacterium that produces a potent biological toxin, and is the causative agent of tetanus. The tetanus toxin is internalized in the postsynaptic neuromuscular neuron binding to a protein, synaptobrevin, located on the surface of synaptic vesicles, where acetylcholine is stored. Tetanus toxin is a proteolytic enzyme, activated by zinc ions. Its activity is extremely specific, it cleaves synaptobrevin, impeding its liberation and causing muscle paralysis.

Corynebacterium diphtheriae produces diphtheria toxin, which acts as an enzyme that transfers adenosyl-diphosphate-ribase (ADPR) of NAD (nicotinamide-adenine-dinucleotide) to the elongation factor 2 and prevents this factor from adding amino acids to the protein chain, thus inhibiting protein synthesis in target cells.

Bordetella pertussis produces pertussis toxin, which like diphtheria toxin, is an enzyme that transfers ADPR to protein targets. Unlike diphtheria toxin, pertussis toxin targets a large number of $G$ proteins, which are part of the receptors present on the membrane of several cell types. When the mediators bind to the receptor, the separate chains of $G$ proteins, $\alpha$ chain, activates adenylate cyclase, that catalyses the formation of cyclic adenylic acid (cAMP). The two other chains of $\mathrm{G}$ proteins ( $\beta$ and $\gamma$ ) activate another enzyme, phospholipase $\mathrm{C}$ producing inositol triphosphate that liberates $\mathrm{Ca} 2+$ in the endoplasmic reticulum activating the phosphorylation of other proteins, among them, cytoskeleton cells. The blockade of receptors elicited by pertussis impedes the separation of $\mathrm{G}$ protein chains, inhibiting the production of adenylate cyclase and the signs mediated by the increase of $\mathrm{Ca} 2+$ and $\mathrm{K}+$ inside the cells. The production of cAMP acts in the transmission of the signal to the cell's interior: $\mathrm{Gi}$ (present in the $\alpha 2$ adrenergic receptors, cholinergicmuscarinic, dopaminergic-D2, glutaminergic,5H-T serotonin, opiate receptors linked to pain, cannabinoid, melatonin, somatostatin, TSH liberation factor), the $G_{t}$, or retina transducine and more than a hundred of $G$ receptors that detect taste and smell, affecting therefore a large number of organs. cAMP activates the phosphorylation of several proteins that regulate glucose and fatty acids metabolism and the contraction of smooth muscle. Unlike tetanus and diphtheria toxins, that present a specific point of action, pertussis toxin blocks several neurotransmitters, affects hormone functions and reduces phagocytic activity ${ }^{5,11}$.

\section{DTP VACCINE}

Diphtheria-tetanus-pertussis (DTP) vaccine was the first combination vaccine, introduced more than 65 years ago, and protects against diseases caused by the three bacteria ${ }^{5}$. It has been recognized since the development of the vaccine against whooping cough that, unlike the protective effect of tetanus and diphtheria toxoids, immunization with pertussis anatoxin alone was not sufficient for protective immunity. Cellular DTP vaccine contains intact heat or formaldehyde inactivated Bordetella pertussis and tetanus and diphtheria toxoids. This combined vaccine has been universally used in the first year of life to prevent morbidity and mortality by whooping cough, tetanus and diphtheria diseases. Instituto Butantan has established new production plants for each one of the DTP vaccine antigen components. New plants have also been established for other antigens, that in the near future will be

(1) Diretora da Divisão Bioindustrial, Instituto Butantan, Av. Vital Brasil 1500, Butantã, 05503-900 São Paulo, SP, Brasil.

(2) Docente do Instituto de Medicina Tropical da USP, Av. Dr. Enéas de Carvalho Aguiar 470, Cerqueira César, 05403-000 São Paulo, SP, Brasil

(3) Médico Instituto da Criança do Hospital das Clínicas da Faculdade de Medicina, USP, Av. Dr. Enéas de Carvalho Aguiar 647, Cerqueira César, 05403-900 São Paulo, SP, Brasil.

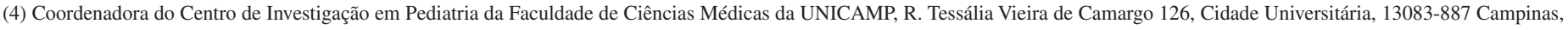
SP, Brasil. 


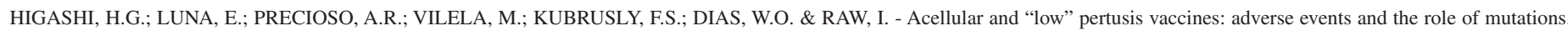
Rev. Inst. Med. trop. S. Paulo, 51(3): 131-134, 2009.

assembled in a 5-valent vaccine (DTP, hepatitis B and Hib), to supply the Brazilian demand. Optimization of production processes, which has been attained after years of experience, has allowed for a 3-4 fold increase in production capacity, well above national demand.

Instituto Butantan's DTP vaccine has been administered free of charge to almost $100 \%$ of newborn children in Brazil in the past 15 years. More than 50 million doses have been used, without major adverse effects. According to the Brazilian Ministry of Health pertussis incidence has declined from 10.8 in 1990 to 0.55 per 100,000 in 2005 . In the same period, diphtheria incidence decreased from 0.45 to 0.01 per 100,000 , and tetanus incidence from 1.0 to 0.25 per 100,000 .

DTP vaccine changes from manufacturer to manufacturer, because of the different Bordetella pertussis strains used for production. Some manufacturers even use two different strains. There is a rare, although serious risk of a severe adverse event related to the pertussis component of DTP. The risk of encephalopathy and convulsions varies according to the origin of the vaccine and the strain used for production. These risks have been estimated to be $1 / 19,496$ for fever convulsions, $1 / 76,133$ for convulsion without fever and 3/106 for encephalopathy ${ }^{5}$.

\section{ACELLULAR PERTUSSIS VACCINE (aP)}

Fear of whole cell pertussis vaccine (wP) toxicity lead, in the seventies, to a decline in vaccine coverage in some countries, increasing whooping cough incidence. To overcome the severe toxicity problem, SATO et al. ${ }^{12}$ developed, in Japan, an acellular vaccine, containing only two major virulence factors of the bacteria, the pertussis toxin (PT) and the filamentous hemagglutinin (FHA), related to the bacterial colonization. The adhesins allow the bacteria to bind the cilliated epithelium of trachea as well as leukocytes. Pertussis toxin is an AB type toxin, where the $\mathrm{B}$ subunit binds to receptors located in the target cells in order to be endocytosed. The A subunit is the toxin itself, with an ADP-ribosyl transferase, that leads to an increase in cAMP, an important intracellular mediator, that in bronchial mucosal cells is responsible for the production of mucus. This toxin also deregulates macrophages, resulting in resistance to phagocytosis. FHA binds to macrophage membranes and inhibits Th1 responses. Bordetella pertussis presents some other virulence factors: fimbriae (Fim), agglutinogens and pertactin (69Kd outer membrane protein), present on the bacterial surface, that allow binding and invasion of host cells; adenylate cyclase, which catalyses the production of cAMP from ATP and induces leukocytosis and insulin secretion, enhancing the immune response; tracheal cytotoxin, that paralyzes tracheal epithelium ciliae; and dermo-necrotic toxin or thermolabil toxin, that induces dermal necrosis and vasoconstriction. The Bordetella resistance to serum killing, antigen (BrkA) protects bacteria from complement attack. SATO's ${ }^{12}$ studies have demonstrated that pertussis anatoxin and FHA are enough to induce protective immunity. Currently, besides these two antigens, some acellular vaccines include pertactin and fimbriae. All acellular vaccines are inactivated by formaldehyde or glutaraldehyde and $\mathrm{H} 2 \mathrm{O} 2$.

\section{COST-BENEFIT DTP VS DTPa}

The aP, with almost similar efficacy of the wP and lower reactogenicity, has been widely used by industrialized countries in combination with tetanus and diphtheria toxoids (DTaP vaccine). However, the profit from production of aP vaccine is extremely low, around ten times less than the traditional wP and its substitution in accordance with the price of Fundo Rotatório da Organização Panamericana de Saúde (OPAS), would increase the cost from US\$ 0.15 to US\$ 8.15.

For Brazil, which administers five pertussis doses for each child, this would represent a cost of 163 million dollars / year and the importation of $\mathrm{DTaP}$ would in turn cause an increase of more than 50 times in the expense. In October of 2007, the Technical Committee Adviser in Immunizations of the OPAS and members of the World Health Organization (WHO) both composed of specialists from several countries joined in Washington and concluded: "There is no reason for countries to substitute the whole cell pertussis vaccine for acellular pertussis vaccine. The use of the wP presents a much higher relation of cost-effectiveness ${ }^{10}$."

\section{DTP CLINICAL TRIALS}

A mistake in the child vaccine production may put at risk all the infant population born at that year. No less serious is the importation of vaccine in bulk without activity, as happened to Butantan Institute before production of its own vaccine preparation had been optimized. Fortunately, the inactive lot was detected in time avoiding the administration of a vaccine that, although harmless, did not give the expected protection.

WHO recommends that each country has a procedure to ensure quality control before releasing each lot of vaccine. Unfortunately, application of such procedures remains limited. Non-producer countries, normally the poorest, are subject to trust in the supplier. Brazil established in 1984 the National Institute of Quality Control in Health (INCQS), which operates along with Oswaldo Cruz Foundation. The INCQS showed that several national and imported vaccines, and specially the hyperimmune serums against serpent poisons, were inactive and frequently contaminated, which led to the closure of many small producers. Recently, similar events occurred in India with DTP manufactures.

Before being released by the producer, the wP basically passes through three laboratory tests: (i) weight gain in mice, a non-specific toxicity test that evaluates loss of weight in mice immunized with the vaccine test lot; (ii) pyrogen testing in rabbits, with the induction of fever to evaluate the level of endotoxin in the product; and (iii) the mouse protection test, using an intracerebral challenge with a virulent B. pertussis strain. These tests are repeated by the INCQS for samples of each lot of vaccine supplied by Instituto Butantan, before its release. Vaccine toxicity is most often due to the presence of lipopolysaccharide (LPS), present in the cell walls of all Gram-negative bacteria. LPS binds to Toll-like receptor 4 found on the surface of leucocytes, activating simultaneously two branches of intracellular signaling: one mediated by the signaling adaptor MyD88, which induces the production of inflammatory cytokines, and other mediators of the inflammatory cascade, and the second mediated by the adaptor TRIF, which induces interferon - $\beta$, and leads to activation of T cells, promoting the adaptive immune response ${ }^{7}$.

Antibody responses are assumed to be related to protection against intracerebral challenge in mice immunized with the pertussis vaccine. It was demonstrated by Instituto Butantan, ${ }^{8}$ in mice immunized with a 
HIGASHI, H.G.; LUNA, E.; PRECIOSO, A.R.; VILELA, M.; KUBRUSLY, F.S.; DIAS, W.O. \& RAW, I. - Acellular and "low" pertusis vaccines: adverse events and the role of mutations. Rev. Inst. Med. trop. S. Paulo, 51(3): 131-134, 2009

BCG recombinant vaccine carrying the gene for production of the subunit $\mathrm{S} 1$ of the pertussis toxin, that this vaccine protects the mice against intracerebral challenge without producing antibodies and, therefore, reflects the action of components of the cellular immunity. This is now a candidate vaccine that, if administered during the first months of life as is true of BCG, would prevent whooping cough in the first months of life, before immunity is induced by the traditional vaccination scheme with DTP, which occurs after the second or third doses given at 4 and 6 months, respectively.

\section{DTP LOW - A NEW CELLULAR PERTUSSIS VACCINE}

Undoubtedly LPS is one of the principal components responsible for the toxic effect of the cellular pertussis vaccine. During the isolation and purification of the protein antigens in the production of acellular vaccine, a major goal is the removal of the LPS. The Instituto Butantan recently developed a process that removes more than $95 \%$ of the LPS, without altering the ultramicroscopic structure of the bacterium, resulting in a cellular pertussis vaccine (Plow), which is much less toxic and equally effective in mice ${ }^{4}$ as measured by the intracerebral challenge. The new vaccine, combined with the tetanus and diphtheria toxoids (DTPlow), was demonstrated in a clinical trial to induce humoral and cellular immune responses similar to DTP and probably equal or superior than $\mathrm{DTPa}^{17}$. Importantly, the production of this vaccine did not alter the cost of the traditional DTP, allowing for its use in developing countries (Fig. 1).

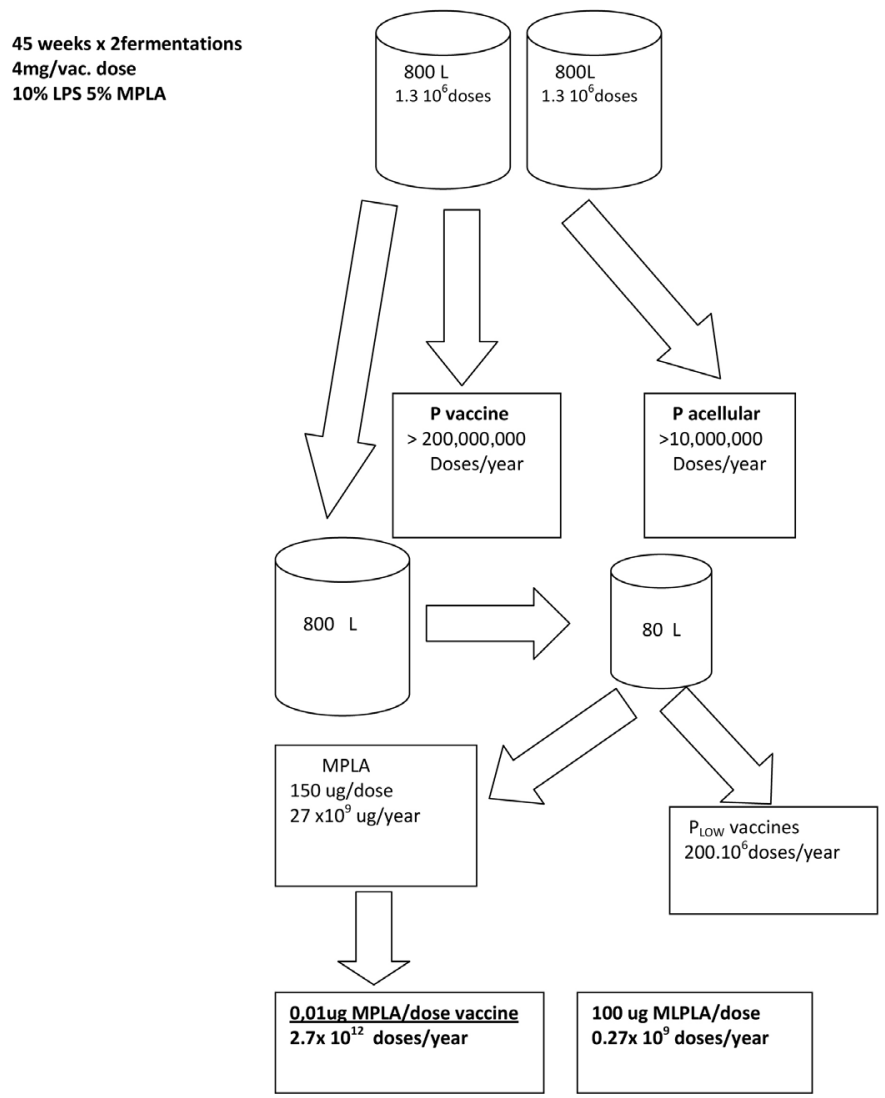

Fig. 1 - Plow and monophosphoryl-lipid A production from pertussis.
In the new process, two other products are obtained, in the same line of production. From the culture supernatant of the bacterium, one obtains a preparation which contains the principal pertussis antigens PT, FHA, pertactin and adenylate cyclase, constituting a new acellular pertussis vaccine (aP), equally of low cost. Studies in progress have demonstrated that is possible to produce for each 10 or 20 doses of the traditional $\mathrm{wP}$ or of the Plow, one dose of the aP vaccine. This vaccine may be used in children who present contraindications for vaccination with wP, or in adolescents ${ }^{3}$, and adults, in which the cellular component is not indicated.

The removed LPS of the bacterium can be processed into monophosphoryl-lipid A (MPLA), a powerful adjuvant, which has been evaluated in different vaccines and elicit the production of interferon - $\beta$ and enhances $\mathrm{T}$ cell activation, without inducing an inflammatory response. In the Instituto Butantan, MPLA obtained from pertussis has been evaluated in mice, as an adjuvant component of an influenza vaccine. In this study, $0.01 \mu \mathrm{g}$ of MPLA reduced by four times the necessary dose of vaccine ${ }^{16}$. A dose of classic wP contains around $400 \mu \mathrm{g}$ of LPS, corresponding to $150-200 \mu \mathrm{g}$ of MPLA. MPLA will be essential as an adjuvant to produce the Asian flu vaccine that have low immunogenic capacity, and which otherwise require, doses much higher than is true of the vaccine for seasonal influenza. Clinical trials of pertussis-derived MPLA are in progress. Reducing the dose of antigens in the seasonal influenza vaccine, and with the same financial resources, will allow inclusion of children of school age to participate in public vaccination campaigns against influenza. In addition to protecting children from influenza, including dissemination of the virus to family members, these campaigns help prevent secondary infections, such as pneumonia and middle ear infections that cause deafness.

\section{MUTATIONS AND VACCINES ADVERSE EFFECTS}

For many years, concerns have been raised about the risk of vaccine-induced childhood encephalopathy and epilepsy. Recently, "The Hannah Poling Case" in The United States had extensive media coverage ${ }^{9}$. When Hannah was at the age of 19 months she received five vaccines: diphtheria-tetanus-acellular pertussis; Haemophilus influenza type b (Hib); measles-mumps-rubella (MMR); varicella; and inactivated polio. Two days later, she was lethargic, irritable, and febrile. Ten days after vaccination, she developed a rash consistent with vaccine-induced varicella. Months later, with delays in neurologic and psychological development, she was diagnosed with encephalopathy caused by a mitochondrial enzyme defect. Her symptoms were compatible with autism spectrum. As Hannah's parents believed that vaccines had triggered her encephalopathy they sued the Department of Health and Human Services (DHHS) for compensation under the Vaccine Injury Compensation Program (VICP) and won. Definitely, the encephalopathy was not caused by the vaccine, but its appearance after the vaccination can suggest that the vaccine accelerated the appearance of the symptoms of this genetic disease.

The association between vaccines and multiple sclerosis or autism has also generated much controversy ${ }^{1}$. In the case of autism, concern was raised that thimerosal-containing vaccines result in children developing neurodevelopmental disorders ${ }^{6}$. However, critical reviews show that neither immunization nor thiomersal exposure are linked to autism. It is worth saying that in developed countries such as Sweden and Denmark, 
HIGASHI, H.G.; LUNA, E.; PRECIOSO, A.R.; VILELA, M.; KUBRUSLY, F.S.; DIAS, W.O. \& RAW, I. - Acellular and "low" pertusis vaccines: adverse events and the role of mutations. Rev. Inst. Med. trop. S. Paulo, 51(3): 131-134, 2009

the diagnoses of autism began in the mid 1980s and continues to increase. However, thimerosal exposure in Sweden and Denmark (already low throughout the 1970s and 1980s) began to decrease in the late 1980s and has been eliminated since the early $1990 \mathrm{~s}^{15}$.

Another concern in vaccination is the observation of neurological disease, such as epilepsy, encephalitis, and encephalopathy, within a few days after DTP. Large-scale studies of this issue have produced conflicting results, although the recent consensus is that the risk of vaccine-induced encephalopathy and/or epilepsy, if it exists at all, is extremely low low $^{2,14}$. In fact, it was shown that encephalopathy in 11 out of 14 children studied, although previously attributed to vaccination, was in fact due to an inherited genetic defect of the $\alpha 1$ chain of the gene SCN1, which is a voltage-gated sodium channel ${ }^{2}$. This mutation causes a clinical manifestation similar to the severe myotonic epilepsy of childhood.

These findings show that the serious side effects considered associated to the DTP vaccine must be in fact due to genetic mutations which are difficult to diagnose routinely. Therefore, the detection of these mutants at the moment should be performed by questioning about potential vaccine side effects occurrence among relatives. Anyway, the occurrence of side effects associated to vaccination always causes public distress, which can make the introduction of a new vaccine difficult, even if effective and safe, afterwards. The research on new vaccine formulations keeps as a goal the discovery of new formulations with no side effects, which is not always easily attainable.

\section{RESUMO}

\section{Vacinas pertussis acelular e pertussis "low": eventos adversos e o papel das mutações}

Objetivo: Discutir as recomendações da WHO-OPAS que não consideram indicada a substituição da vacina DTP celular clássica pela DTP acelular e o papel de mutações, em humanos, como principal causa dos raros eventos de convulsões epileptiformes desencadeadas pela vacina pertussis.

Revisão dos dados: Os principais componentes relacionados aos efeitos tóxicos da vacina pertussis celular são o lipopolissacarídio da parede celular da bactéria e a toxina pertussis. A remoção de parte da camada lipopolissacarídica permitiu a criação de uma vacina pertussis celular, mais segura e de custo comparável ao da vacina celular tradicional, podendo substituir a vacina pertussis acelular.

Conclusão: A nova vacina pertussis, com baixo teor de LPS (Plow) desenvolvida pelo Instituto Butantan, além de oferecer uma vacina mais segura, permite o aproveitamento do lipopolissacarídeo para a produção de monofosforil lipídeo A. Esse componente mostrou-se potente como adjuvante e altamente eficiente quando administrado com a vacina de influenza, levando à possibilidade de se reduzir a dose de antígeno, aumentando a capacidade de produção e redução dos custos.

\section{REFERENCES}

1. BALE, L.F. - Neurologic complications of immunization. J. Child Neurol., 19: 405-412, 2004

2. BERKOVIC, F.; McMAHON, J.M.; PELEKANOS, J.T. et al. - De-novo mutations of the sodium channel gene $\mathrm{SCN} 1$ in alleged vaccine encephalopathy: a retrospective study. Lancet Neurology., 5: 488-492, 2006.

3. CARVALHO, S.P. \& PEREIRA, E.M.C. - Acellular pertussis vaccine for adolescents. J. Pediat. (Rio de J.), 82(suppl. 3): S15-S24, 2006.

4. DIAS, W.O. - Patent deposited. Publication in preparation.

5. EDWARDS, K.M. \& DECKER, M.D. - Pertussis vaccine. In: PLOTKIN, S. \& ORENSTEIN, W.A. Vaccine. 4. ed. Philadelphia, Saunders, 2004.

6. GEIER, D. \& GEIER, M.R. - Neurodevelopmetal disorders following thiomersalcontaining childhood immunizations: a follow-up analysis. Int. J. Toxicol., 23: $369-376,2004$

7. MATA-HARO, V.; CEKIC, C.; MARTIN, M. et al. - The vaccine adjuvant monophosphoryl lipid A a TRFI-biased agonist of TLR4. Science, 316: 1628-1232, 2007.

8. NASCIMENTO, I.P.; DIAS, W.O.; QUINTILIO, N. et al.- Neonatal immunization with a single dose of recombinant $\mathrm{BCG}$ expressing subunit $\mathrm{S} 1$ from pertussis toxin induces complete protection against Bordetella pertussis intracerebral challenge. Microbes and Infection, 10: 198-202, 2008.

9. OFFIT, P.A. - Vaccines and autism revisited - The Hannah Poling Case. New Engl. J. Med., 358: 2089-2091, 2008.

10. PAHO - Immunization newsletter, 29(6), December, 2007.

11. RAW, I. \& HO, P.L. - Integração e seus sinais. São Paulo, Editora Unesp, 2000.

12. SATO, Y.; KIMURA, M. \& FUKUMI, H. - Development of pertussis component vaccine in Japan. Lancet, 1: 122-126, 1984.

13. SELL, E. \& MINASSIAN, B.A. - Demystifying vaccination-associated encephalopathy. Lancet Neurology., 5: 465-466, 2006.

14. SHORVON, S. \& BERG, A. - Pertussis vaccination and epilepsy- erratic history, new research and mismatch between science and social policy. Epilepsia, 49: 219-225, 2008 .

15. STEHR-GREEN, P.; TULL, P.; STELLFELD, M.; MORTENSON, P.B. \& SIMPSON, D. - Autism and thiomersal-containing vaccines: lack of consistent evidence for an association. Amer. J. prevent. Med., 25: 101-106, 2003.

16. WAGNER, Q. - Patent deposited. (Publication in preparation).

17. ZORZETO, T.D. et al. - Immunogenicity of low lipopolyssacharide (LPS) cellular Bordetella petussis vaccine among infants; $\Gamma \delta+\mathrm{T}$ cell expansion in infants vaccinated with low lipopolyssacharide cellular pertussis (DTwPlow) or wholecell pertussis (DTwP) vaccines. In: VACCINE CONGRESS, 2007, Amsterdam.

Received: 18 November 2008

Accepted: 7 April 2009 